\title{
Taboo Words in Movie Sequels 21 and 22 Jump Street
}

\author{
Ni Luh Dianty Saraswati Giri ${ }^{1^{*}}$, I Gede Budiasa ${ }^{2}$ \\ ${ }^{[12]}$ English Department - Faculty of Arts - Udayana University \\ ${ }^{1}$ [saraswatigiri2396@gmail.com] ${ }^{2}$ [budiasa.igede@yahoo.com] \\ *Corresponding Author
}

\begin{abstract}
The current study entitled "Taboo Words in Movie Sequels 21 and 22 Jump Street" aims to identify the types, functions and the dominant type of taboo words uttered by the characters in the movies 21 and 22 Jump Street.The data in this study were chosen from the conversations among the characters in the movies, and were collected through documentation method. This study applied qualitative method for analyzing the types and functions of taboo words in the movies. In addition, this study also used quantitative method to see the dominant types of taboo words in the movie, in a form of percentage. The results of the analysis are stated as follows. Firstly, four types of taboo words occur in the characters' utterances in the movies 21 and 22 Jump Street. They are obscenity, profanity, vulgarity and epithet. Secondly, four functions of taboo words were also found in the movies namely to show contempt, to draw attention to oneself, to be provocative, and to mock authority. The dominant type of taboo words in both movies is Obscenity type.
\end{abstract}

Keywords: taboo words, type, function, and the dominant type.

\section{Abstrak}

Penelitian ini yang berjudul bahasa tabu di sekuel film 21 dan 22 Jump Street bertujuan untuk mengidentifikasi jenis, fungsi dan tipe dominan dari bahasa tabu yang diucapkan oleh karakter di dalam film 21 dan 22 Jump Street. Data dalam penelitian ini dipilih dari percakapan antara karakter di dalam film, dan dikumpulkan melalui metode dokumentasi. Penelitian ini menggunakan metode kuatitatif untuk menganalisis jenis dan fungsi dari bahasa tabu di dalam film. Selain itu penelitian ini juga menggunakan metode kuantitatif untuk melihat jenis bahasa tabu yang dominan di dalam film, dalam bentuk persentase. Hasil analisis dinyatakan sebagai berikut. Pertama, empat jenis bahasa tabu muncul dalam ucapan para karakter dalam film 21 dan 22 Jump Street. Antara lain obscenity, profanity, vulgarity dan epithet. Kedua empat fungsi bahasa tabu juga ditemukan di dalam kedua film tersebut yaitu to show contempt, to draw attention to oneself, to be provocative, dan to mock authority. Jenis bahasa tabu yang dominan di kedua film adalah jenis obscenity.

Kata kunci: bahasa tabu, jenis, fungsi, dan tipe dominan.

\section{Background}

According to Wardaugh (2000: 234), taboo is the prohibition or avoidance in any society of behavior believed to be harmful to its members in that it words that lead to anxiety, embarrassment, or shame. Taboo subjects can vary widely: sex, death, illness, excretion, bodily functions, religious matters, and the supernatural. However, amongst the taboo words used to refer to illness, death and the 
supernatural are rarely used. But quite often they extend to other aspects of social life.

Taboo words are commonly used in public, the existence of taboo words at the present time, for example in the movie, song lyric, or TV show. The use of taboo words are believed to be able to express emotion and a strong feelings.

This study focuses on the analysis of taboo words, since we can see or hear the use of taboo words everywhere even in public. It is very interesting to analyze, because from this research we can know various types of taboo words and what exactly the function of taboo words. Also by knowing the dominant types in this study, we can know the type of taboo words commonly used in public. By knowing the type and function of taboo words, we can understand what exactly the purpose of using those words, so we will not be offended when someone uses the inappropriate words. In conducting the research, a movie was chosen as the source of data, since the movie is the representation of human real life.

For the data source, the researcher uses two movies; they are 21 Jump Street and 22 Jump Street. Those movies were chosen because the characters in the movies use a lot of taboo words in their conversations, so it can be analyzed easily.

\section{Problems of The Study}

a. What types of taboo words are used in the movies 21 Jump Street and 22 Jump Street?

b. How do the taboo words function in the movies 21 Jump Street and 22 Jump Street?

c. What are the dominant types of taboo words in the movies 21 Jump Street and 22 Jump Street?

\section{Aims of The Study}

a. To describe the types of taboo used in the movies 21 Jump Street and 22 Jump Street .

b. To analyze the functions of taboo words uttered by the characters in the movies 21 Jump Street and 22 Jump Street.

c. To identify the dominant types of taboo words in the movies 21 Jump Street and 22 Jump Street.

\section{Research Method}

The sources of the data are the video of the movies and the script of the dialogue spoken by the characters in the movies 21 Jump Street and 22 Jump Street. The movies were chosen as the data sources because there were a lot of taboo words in the dialogues of the movie. Also, these movies have many variations of taboo words.

Data of this study were collected from the movies 21 Jump Street and 22 Jump Street through documentation and the following steps: Watching the movie, note taking the words that may contain taboo words, downloading the script, sorting the collected data, and analyzing the data using two theories related to the research.

In this study the data were analyzed using the qualitative method in two steps: First, categorizing the taboo words based on the types using the theory proposed by Batistella (2005: 72). Second, classifying the function of taboo words using the theory proposed by Wardhaugh (2006: 239).

This study was also quantitatively analyzed in two steps: First, classified the taboo words based on their types. Second, counting the taboo words to see the dominant types of taboo words in the movies.

In order to present the data, this study used the descriptive method combined with quantitative. First, the 
data were categorized based on their scene. Second, the conversations in that scene were written. Finally, each data was presented descriptively and quantitatively.

\section{Findings and Discussion}

5.1 Types and Functions of Taboo Words in the Movie 21 Jump Street

\section{a. In school hallway}

Melodie : Oh, my God. You're not asking me to prom, are you?

Schmidt : Oh, fuck! No! No! II...no! No, I just...I mean, you probably going with someone.

Melodie : I'm sorry. I don't know how to put this nicely.

Jenko : There's not a nice way to put it. You're a fucking nerd. And, you know, she's, I don't know, she's hot. Look at her. Look at her. Look at her! Look at her! (00:02:11)

In the first exchange, Schmidt said "Oh, fuck! No! No! I-I...no! No, I just...I mean, you probably going with someone". In the second exchange Jenko said "You're a fucking nerd". The word fuck and fucking spoken by Schmidt and Jenko were considered taboo words, because fuck actually means to have sex with somebody. Therefore, we can categorize the word fuck and fucking as obscenity

The word fuck spoken by Schmidt serves to dwar attention to oneself, which means Schmidt uttered the strong word to attract Melodie's attention. While the word fucking spoken by Jenko used to emphasize a comment or an angry statement. This kind of expression is categorized as showing contempt.

\section{b. In parking lot}

Tom Hanson : If them boys is cops, I'm DEA.
Schmidt : I know! Right? I know! It's hilarious. So why don't you show us a little respect?

Domingo : Fuck you, pig!

Jenko : Hey! You want me to

beat your dick off? (00:07:05)

Domingo : You want to beat my dick off?

Jenko : I'll beat your dick off with both hands. What's up? Let's go.

In this case, the word dick belongs to vulgarity type. The sentence was spoken by Jenko was used to threaten and provoke the anger from Domigo. Therefore, this expression serves as the provocative function.

\section{c. Captain Dickson's office}

Captain Dickson : Now, you two sons of bitches in my office, now! Right now! It's a new synthetic drug, goes by the street name, HFS.

Jenko : They put this on the internet for everybody to see?

Captain Dickson : $\quad$ They're teenager, man. They're really stupid, so you should blend right in.

Jenko : I could watch this all day! (00:14:18)

Captain Dickson said "sons of bitches" to Schmidt and Jenko, and the expression is considered epithet , because he was mentioning the word bitches. The function of this expression serves to show contempt, because he has a higher position than them; therefore, he thinks Schmidt and Jenko cannot be respected.

\section{d. In front of Jesus statue} Captain Dickson : Hey! Hey! Stop fucking with Korean Jesus! He ain't got time for your problems! He's busy, with Korean shit! You two get to your mama's house, ASAP!

Schmidt : What? 
Captain Dickson : You're teenagers now! Alright? You two are stayin' at Schmidt's parents' house for the duration of this assignment. (00:18:07)

There were two types of taboo words found in this conversation; both of them were spoken by Captain Dickson in one sentence. The first phrase that he said was "fucking with Korean Jesus!".

The use of taboo word with God's name is categorized as profanity. The second taboo was Korean shit, this kind of expression is categorized as epithet type, because this expression contains ethnic slurs. Those types of taboo have the same functions as drawing attention to oneself. Captain Dickson used strong language to get attention from Schmidt.

\subsubsection{The Dominant Type of Taboo} Words Used in 21 Jump Street Movie

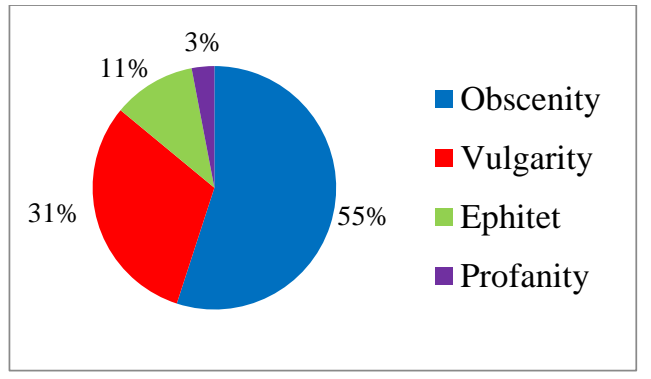

The chart showed that Obscenity type was the most commonly used in the movie (55\%). There are three words categorized as Obscenity type based on the movie including fuck, shit and masturbate. The second type of taboo word that was often used was Vulgarity (31\%), next was Epithet type (11\%), the last one was Profanity type with (3\%).

\subsection{Types and Function of Taboo Words in 22 Jump Street Movie}

\section{a. Inside the church}

$$
\begin{aligned}
& \text { Captain Dickson : Fuck } 21 \text { Jump } \\
& \text { Street, and fuck the Korean Jesus. }
\end{aligned}
$$

Jenko : Ooh, Cap, come on. [pointing to the massive statue opposite them] Korean Jesus is right there.

Captain Dickson : That's Vietnamese Jesus. See, this a Vietnamese Church, you racist sacrilegious sack of shit. Look at that. Vietnamese Jesus just drippin' swagoo. And we got some new dumb-ass interns. [to the interns] Hey, hey! Look alive!

Jenko : Ha-ha! Boys!
$(00: 11: 26)$

Based on the conversation, in the first line Captain Dickson said "Fuck 21 Jump Street" the word fuck is categorized as obscenity, and in this case Captain Dickson uttered the word to express his anger. In the same line Captain Dickson also said "fuck the Korean Jesus" this expression was containing God's name; therefore, this expression is categorized as profanity. The expression spoken by Captain Dickson serves to mock authority function. Captain Dickson said fuck to 21 Jump Street and Korean Jesus to express his dissatisfaction to some institution and nationality.

In the same exchange Captain Dickson said "you racist sacrilegious sack of shit" to Jenko. This expression is categorized as profanity, because there was a word about religious concept contained in it. The function of the taboo word serves to show contempt. Captain Dickson used those strong words to insult Jenko and thought he was stupid and racist.

In the same line Captain Dickson also said "dumb-ass" to his new interns, the word Ass means the bottom part of human's body; therefore, this word is categorized as vulgarity, and in this case dumb-ass means a stupid person. 
Captain Dickson uttered that taboo word in order to show contempt.

\section{b. At the open mic night}

Slam Poet \#2 : My brown nipple will produce white milk during lactation.

Schmidt : [to Maya as they watch the poet] What do you think of this?

Maya : I actually think it's really powerful.

Schmidt : That's cool that you said that cause I actually thought it was really powerful too, when a girl is talking about her...her nips and shit. (00:21:50)

The word nipple in her poem is considered a taboo word, because she was mentioning the two small round dark parts on a person's chest. Therefore, the word nipple is categorized as vulgarity type of taboo word.

The female student uttered the strong word in order to draw attention to oneself, because she wanted to attract the attention from the audience in that club.

\section{c. In abandoned library}

Jenko : Fine. [suddenly Jenko turns and head butts the goon who collapses to the floor] [Jenko takes off his football helmet as she faces Ghost and his goons] Oh, yeah! What's up now, motherfuckers! You remember me? I'm your best nightmare...I'm your worst nightmare.

The Ghost : Oh, man. It's my memory, it's getting worse lately. Are you the police?

Jenko : Yeah, that's right. And you motherfuckers are all under arrest. (01:11:37)

This conversation happened when Jenko and Schmidt were finally meeting face to face with The Ghost, he said The
Ghost was a motherfucker. The word motherfucker is considered a taboo word because it contains a sexual slur. That is categorized as epithet type.

In this case, Jenko uttered the word to show his dislike to The Ghost, also in order to be provocative as he wanted to provoke the anger from The Ghost by saying that he was the worst nightmare for The Ghost, he also said The Ghost and his man will be arrested.

\section{d. In front of Mr. Walter's Jail}

Mr. Walters : Ho! If it isn't Turner and Hooch in the flesh! [to Jenko] Holy shit, you are looking fit! $\mathrm{Mm}$ ! [shouting to Eric in he cell behind him] Hey! You should get some tip from this guy, he's looking good! Look at those pectoral muscles. That's the kind of definition I want out of you, man.

Jenko : What's up, Eric

Eric Molson : Hey. (00:24:30)

When Mr. Walters saw Jenko he said "Holy shit". This kind of expression was categorized as profanity type because there was the word Holy in it which connected with God or a particular religion.

He said the word to attract the attention from Jenko, also to emphasize that he was surprised when he saw Jenko with pectoral muscles. This expression serves to draw attention to oneself.

\subsubsection{The Dominant Type of Taboo Words used in the movies 22 Jump Street}

The dominant type of taboo words in the movies 22 Jump Street was represented as below: 


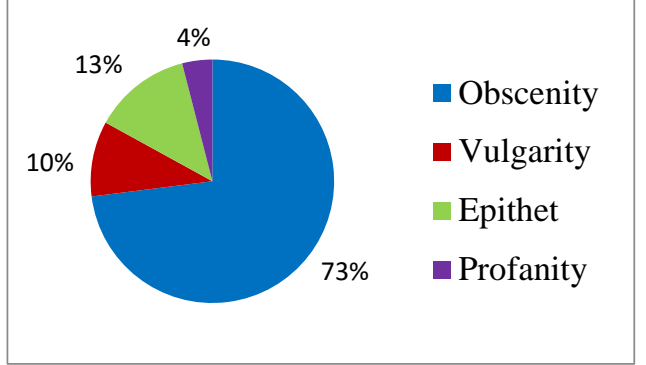

The chart showed that Obscenity type has the most dominate appearances of the type with $(73 \%)$. The characters in the movie were mentioning three words categorized as Obscenity , including fuck, shit and cum, the type of taboo word that showed $(13 \%)$ on the percentage was Epithet type, the type of taboo word with (10\%) was Vulgarity, the last type of taboo words that showed (4\%) on the percentage was Profanity type.

\section{Conclusion}

The movies 21 Jump Street and 22 Jump Street have all four types of taboo words, including epithet, profanity, vulgarity and obscenity according to Batistella. Those movies also have all four functions of taboo words based on Wardaugh's theory, they are: to draw attention to oneself, to show contempt, to be provocative, and to mock authority functions. The dominant types of taboo words in 21 Jump Street movie is Obscenity with $(55 \%)$, and in the movie 22 Jump Street the dominant type of taboo words is Obscenity with $(73 \%)$.

\section{References}

Batistella, E.L.(2005). Bad Language:

Are Some Words Better Than

Others? (tesis). New York:

Oxford University Press.

Fromkin, V. (2005).An Introduction to

Language. United state of

America: Thompson

Corporation.
Gao, C. (2013). Theory and Practice in Language Studie [Internet]. Academy Publisher, China. Available from: http://www.academypublication.c om/issues/past/tpls/vol03/12/23.p $\underline{\mathrm{df}}$

Hornby, A. S. (2000). Oxford Advance Learner's Dictionary sixth edition. Oxford University Press, New York.

Wardaugh, R. (2006). An Introduction to Sociolinguistics (Fifth Edition). Oxford: Blackwell Publishing Ltd. 